\title{
Genome sequence of Ensifer sp. TW10; a Tephrosia wallichii (Biyani) microsymbiont native to the Indian Thar Desert
}

\author{
Nisha Tak', Hukam S Gehlot', Muskan Kaushik', Sunil Choudhary ${ }^{1}$, Ravi Tiwari², Rui Tian², \\ Yvette Hill2 $^{2}$, Lambert Bräu ${ }^{3}$, Lynne Goodwin ${ }^{4}$, James Han ${ }^{5}$, Konstantinos Liolios ${ }^{5}$, Marcel \\ Huntemann $^{5}$, Krishna Palaniappan ${ }^{6}$, Amrita Pati ${ }^{5}$, Konstantinos Mavromatis ${ }^{5}$, Natalia \\ Ivanova $^{5}$, Victor Markowitz ${ }^{6}$, Tanja Woyke ${ }^{5}$, Nikos Kyrpides ${ }^{5}$ \& Wayne Reeve*2 \\ ${ }^{1}$ BNF and Stress Biology Lab, Department of Botany, JNV University, Jodhpur, India \\ ${ }^{2}$ Centre for Rhizobium Studies, Murdoch University, Western Australia, Australia \\ ${ }^{3}$ School of Life and Environmental Sciences, Faculty of Science, Engineering and Built \\ Environment, Deakin University, Melboume, Victoria, Australia \\ ${ }^{4}$ Los Alamos National Laboratory, Bioscience Division, Los Alamos, New Mexico, USA \\ ${ }^{5}$ DOE Joint Genome Institute, Walnut Creek, California, USA \\ ${ }^{6}$ Biological Data Management and Technology Center, Lawrence Berkeley National \\ Laboratory, Berkeley, California, USA \\ *Correspondence: Wayne Reeve (W.Reeve@murdoch.edu.au)
}

Keywords: root-nodule bacteria, nitrog en fixation, rhizobia, Alphaproteobacteria

Ensifer sp. TW10 is a novel $\mathrm{N}_{2}$-fixing bacterium isolated from a root nodule of the perennial legume Tephrosia wallichii Graham (known locally as Biyani) found in the Great Indian (or Thar) desert, a large arid region in the northwestern part of the Indian subcontinent. Strain TW10 is a Gramnegative, rod shaped, aerobic, motile, non-spore forming, species of root nodule bacteria (RNB) that promiscuously nodulates legumes in Thar Desert alkaline soil. It is fast growing, acid-producing, and tolerates up to $2 \% \mathrm{NaCl}$ and capable of growth at $40 \mathrm{C}$. In this report we describe for the first time the primary features of this Thar Desert soil saprophyte together with genome sequence infomation and annotation. The $6,802,256$ bp genome has a GC content of $62 \%$ and is arranged into 57 scaffolds containing 6,470 protein-coding genes, 73 RNA genes and a single rRNA operon. This genome is one of 100 RNB genomes sequenced as part of the DOE Joint Genome Institute 2010 Genomic Encyclopedia for Bacteria and Archaea-Root Nodule Bacteria (GEBA-RNB) project.

\section{Introduction}

The Great Indian (or Thar) Desert is a large, hot, arid region in the northwestern part of the Indian subcontinent. It is the 18th largest desert in the world covering 200,000 square $\mathrm{km}$ with $61 \%$ of its landmass occupying Western Rajasthan. The landscape occurs at low altitude $(<1500 \mathrm{~m}$ above sea level) and extends from India into the neighboring country of Pakistan [1]. The Thar Desert region is characterized by low annual precipitation (50 to $300 \mathrm{~mm}$ ), high thermal load and alkaline soils that are poor in texture and fertility [2]. Despite these harsh conditions, the Thar Desert has very rich plant diversity in comparison to other desert landscapes [3]. Approximately a quarter of the plants in the Thar Desert are used to provide animal fodder or food, fuel, medicine or shelter for local inhabitants [4].
The Indian Thar desert harbors several native and exotic plants of the Leguminoseae family [2] including native legume members of the subfamilies Caesalpinioideae, Mimosoideae and Papilionoideae that have adapted to the harsh Thar desert environment [5]. The Papilionoid genus Tephrosia can be found throughout this semiarid to arid environment and these plants are among the first to grow after monsoonal rains. The generic name is derived from the Greek word "tephros" meaning "ash-gray" since dense trichomes on the leaves provide a greyish tint to the plant. Many species within this genus produce the potent toxin rotenone, which historically has been used to poison fish. It is a perennial shrub that has adapted to the harsh desert conditions by producing a long tap root system and dormant auxillary shoot buds. 
Recently, the root nodule bacteria (RNB) microsymbionts capable of fixing nitrogen in symbiotic associations with Tephrosia have been characterized [5]. Both Bradyrhizobium and Ensifer were present within nodules, but a particularly high incidence of Ensifer was noted [5]. Ensifer was found to occupy the nodules of all four species of Tephrosia examined [5]. Here we present a preliminary description of the general features of the $T$. wallichii (Biyani) microsymbiont Ensifer sp. TW10 together with its genome sequence and annotation.
Minimum Information about the Genome Sequence (MIGS) is provided in Table 1. Figure 1 shows the phylogenetic neighborhood of Ensifer sp. strain TW10 in a $16 \mathrm{~S}$ rRNA sequence based tree. This strain has $99 \%$ sequence identity at the $16 \mathrm{~S}$ rRNA sequence level to E. kostiense LMG 19227 and 100\% 16S rRNA sequence identity to other Indian Thar Desert Ensifer species (JNVU IC18 from a nodule of Indigofera and JNVU TF7, JNVU TP6 and TW8 from nodules of Tephrosia).

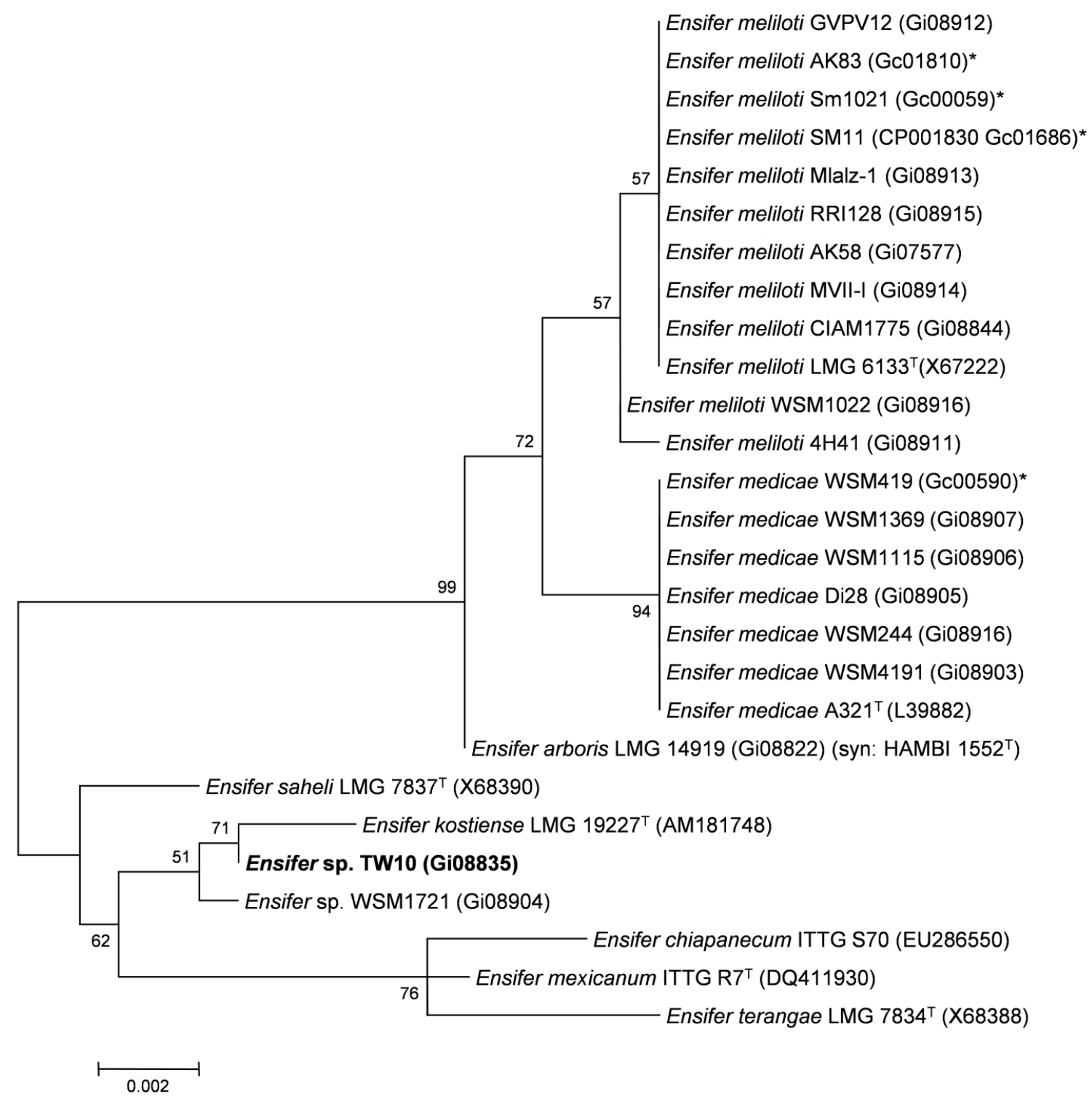

Figure 1. Phylogenetic tree showing the relationship of Ensifer sp. TW10 (shown in bold print) to other Ensifer spp. in the order Rhizobiales based on aligned sequences of the 16S rRNA gene (1,290 bp internal region). All sites were informative and there were no gap-containing sites. Phylogenetic analyses were performed using MEGA, version 5 [19]. The tree was built using the Maximum-Likelihood method with the General Time Reversible model [20]. Bootstrap analysis [21] with 500 replicates was performed to assess the support of the clusters. Type strains are indicated with a superscript T. Brackets after the strain name contain a DNA database accession number and/or a GOLD ID (beginning with the prefix G) for a sequencing project registered in GOLD [22]. Published genomes are indicated with an asterisk. 
Table 1. Classification and general features of Ensifer sp. TW10 according to the MIGS recommendations [6]

\begin{tabular}{|c|c|c|c|}
\hline MIGS ID & Property & Term & Evidence code \\
\hline & \multirow{7}{*}{ Current classification } & Domain Bacteria & TAS [7] \\
\hline & & Phylum Proteobacteria & TAS [8] \\
\hline & & Class Alphaproteobacteria & TAS $[9,10]$ \\
\hline & & Order Rhizobiales & TAS $[10,11]$ \\
\hline & & Family Rhizobiaceae & TAS $[12,13]$ \\
\hline & & Genus Ensifer & TAS [14-16] \\
\hline & & Species Ensifer sp. & IDA \\
\hline & Gram stain & Negative & IDA \\
\hline & Cell shape & Rod & IDA \\
\hline & Motility & Motile & IDA \\
\hline & Sporulation & Non-sporulating & NAS \\
\hline & Temperature range & Mesophile & NAS \\
\hline & Optimum temperature & $28^{\circ} \mathrm{C}$ & NAS \\
\hline & Salinity & Non-halophile & NAS \\
\hline \multirow[t]{3}{*}{ MIGS-22 } & Oxygen requirement & Aerobic & TAS [5] \\
\hline & Carbon source & Varied & NAS \\
\hline & Energy source & Chemoorg anotroph & NAS \\
\hline MIGS-6 & Habitat & Soil, root nodule, on host & TAS [5] \\
\hline MIGS-15 & Biotic relationship & Free living, symbiotic & TAS [5] \\
\hline \multirow[t]{3}{*}{ MIGS-14 } & Pathog enicity & Non-pathog enic & NAS \\
\hline & Biosafety level & 1 & TAS [17] \\
\hline & Isolation & Root nodule of Tephrosia wallichii & TAS [5] \\
\hline MIGS-4 & Geog raphic location & Jodhpur, Indian Thar Desert & TAS [5] \\
\hline MIGS-5 & Soil collection date & Oct, 2009 & IDA \\
\hline MIGS-4.1 & Long itude & 73.021177 & IDA \\
\hline MIGS-4.2 & Latitude & 26.27061 & IDA \\
\hline MIGS-4. 3 & Depth & $15 \mathrm{~cm}$ & \\
\hline MIGS-4.4 & Altitude & Not recorded & \\
\hline
\end{tabular}

Evidence codes - IDA: Inferred from Direct Assay; TAS: Traceable Author Statement (i.e., a direct report exists in the literature); NAS: Non-traceable Author Statement (i.e., not directly observed for the living, isolated sample, but based on a generally accepted property for the species, or anecdotal evidence). These evidence codes are from the Gene Ontology project [18]. 


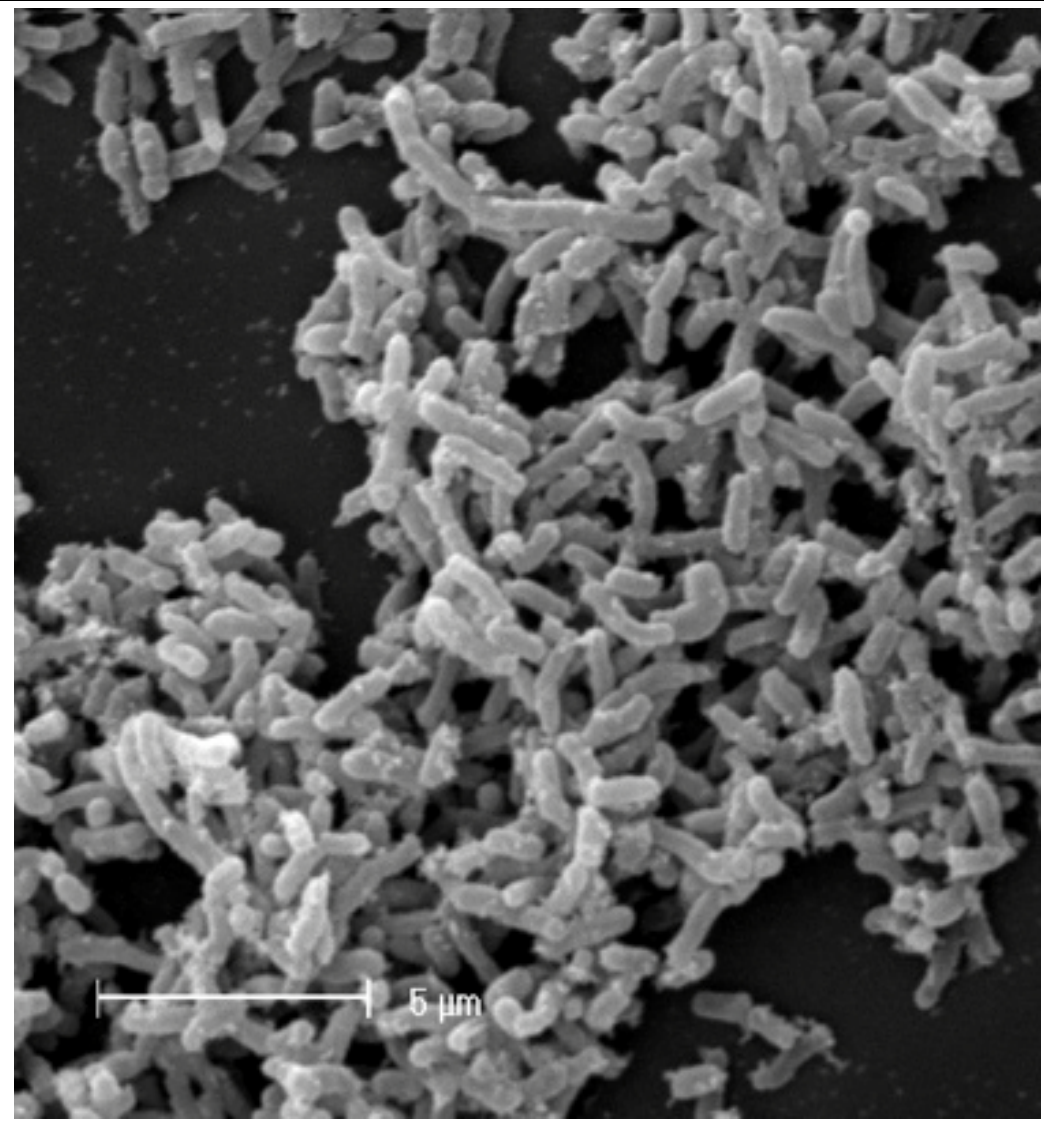

Figure 2. Image of Ensifer sp. TW10 using scanning electron microscopy.

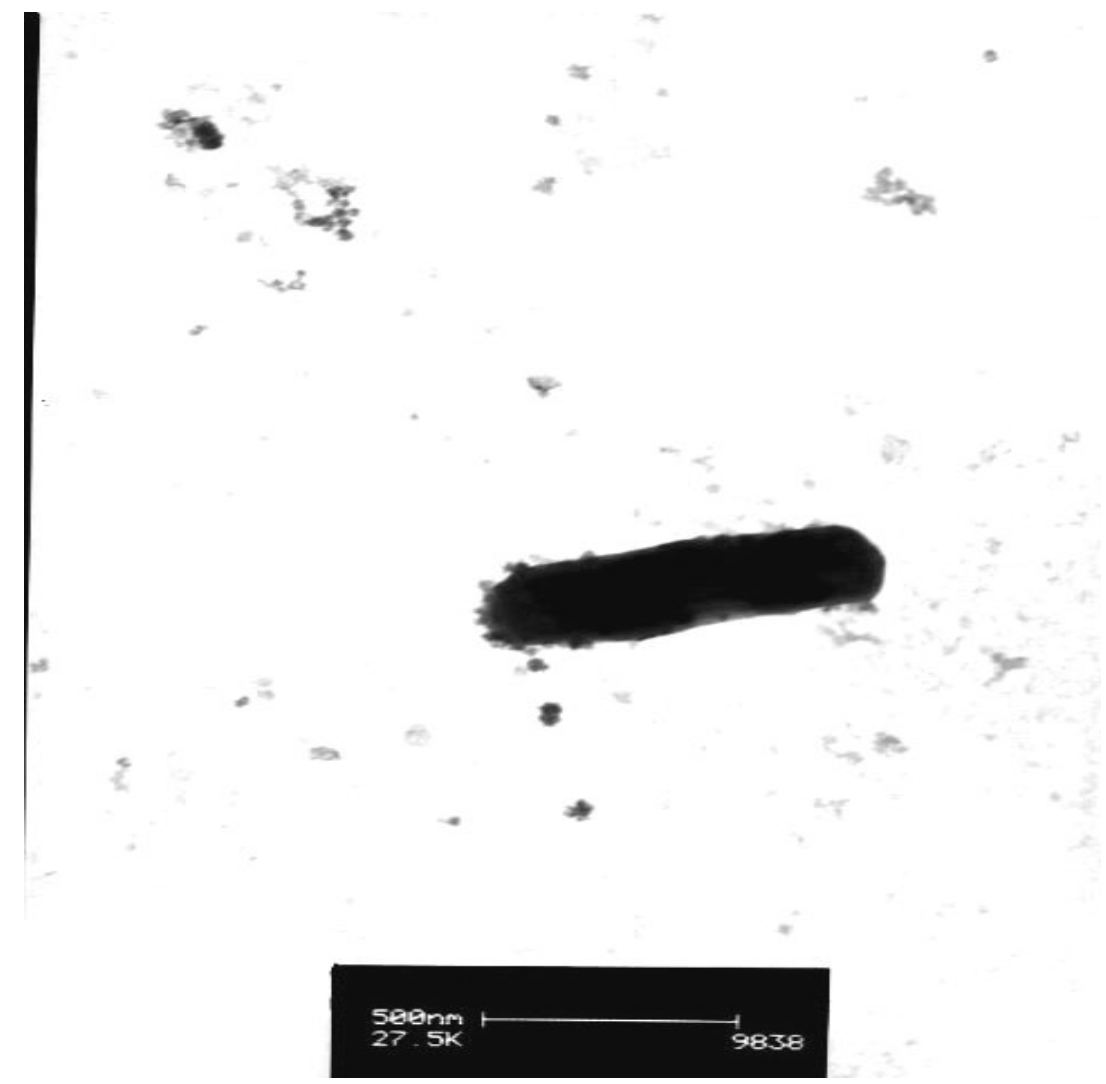

Figure 3. Image of Ensifer sp. TW10 using transmission electron microscopy. 


\section{Classification and general features}

Ensifer sp. strain TW10 is a Gram-negative rod (Figure 2, and Figure 3) in the order Rhizobiales of the class Alphaproteobacteria. It is fast growing, forming white-opaque, slightly domed and moderately mucoid colonies with smooth margins within 3-4 days at $28^{\circ} \mathrm{C}$ when grown on YMA [23].

\section{Symbiotaxonomy}

Ensifer sp. TW10 has the ability to nodulate $\left(\mathrm{Nod}^{+}\right)$ and fix nitrogen $\left(\mathrm{Fix}^{+}\right)$effectively with a wide range of perennial native (wild) legumes of Thar Desert origin and with species of crop legumes (Table 2). Ensifer sp. TW10 is symbiotically competent with these species when grown in alkaline soils. TW10 can nodulate the wild tree legume Prosopis cineraria of the Mimosoideae subfamily. However, it does not form nodules on the Mimosoid hosts Mimosa hamata and M. himalayana even though these hosts are known to be nodulated by Ensifer species $[5,24]$. TW10 was not compatible with the host Phaseolus vulgaris, a legume of the Phaseolae tribe.

Table 2. Compatibility of Ensifer sp. TW10 with different wild and cultivated leg ume species

\begin{tabular}{|c|c|c|c|c|c|c|}
\hline Species Name & Family & $\begin{array}{l}\text { Wild/ } \\
\text { Cultivar }\end{array}$ & $\begin{array}{l}\text { Common } \\
\text { Name }\end{array}$ & $\begin{array}{l}\text { Habit/ } \\
\text { Growth Type }\end{array}$ & Nod & Fix \\
\hline $\begin{array}{l}\text { Tephrosia falciformis } \\
\text { Ramaswami }\end{array}$ & Papilionoideae & Wild & $\begin{array}{l}\text { Rati } \\
\text { biyani }\end{array}$ & Under-shrub Perennial & + & + \\
\hline $\begin{array}{l}\text { Tephrosia purpurea } \\
\text { (L.) Pers. sub sp. } \\
\text { leptostachya DC. }\end{array}$ & Papilionoideae & Wild & - & Herb Annual/ Perennial & + & + \\
\hline $\begin{array}{l}\text { Tephrosia purpurea } \\
\text { (L.) Pers. sub sp. } \\
\text { purpurea (L.) Pers }\end{array}$ & Papilionoideae & Wild & $\begin{array}{l}\text { Biyani, } \\
\text { Sarphanko }\end{array}$ & Herb Annual/ Perennial & + & + \\
\hline $\begin{array}{l}\text { Tephrosia villosa } \\
\text { (Linn.) Pres. }\end{array}$ & Papilionoideae & Wild & $\begin{array}{l}\text { Ruvali- } \\
\text { biyani }\end{array}$ & Herb Annual/ Perennial & + & + \\
\hline $\begin{array}{l}\text { Prosop is cineraria } \\
\text { (Linn.) Druce. }\end{array}$ & Mimosoideae & $\begin{array}{l}\text { Wild/ } \\
\text { Cultivar }\end{array}$ & Khejari & Tree Perennial & + & + \\
\hline Mimosa hamata Willd. & Mimosoideae & Wild & $\begin{array}{l}\text { Jinjani, } \\
\text { Jinjanio }\end{array}$ & Shrub Perennial & - & - \\
\hline M. himalayana Gamble & Mimosoideae & Wild & Hajeru & Shrub Perennial & - & - \\
\hline $\begin{array}{l}\text { Vigna radiata } \\
\text { (L.) Wilczek }\end{array}$ & Papilionoideae & Cultivar & $\begin{array}{l}\text { Moong } \\
\text { bean }\end{array}$ & Annual & + & + \\
\hline $\begin{array}{l}\text { Vigna aconitifolia } \\
\text { (Jacq.) Marechal }\end{array}$ & Papilionoideae & Cultivar & $\begin{array}{l}\text { Moth } \\
\text { bean }\end{array}$ & Annual & + & + \\
\hline $\begin{array}{l}\text { Vigna unguiculata } \\
\text { (L.) Walp. }\end{array}$ & Papilionoideae & Cultivar & Cowpea & Annual & + & + \\
\hline $\begin{array}{l}\text { Macroptilium atropurpureum } \\
\text { (DC.) Urb. }\end{array}$ & Papilionoideae & Cultivar & $\begin{array}{l}\text { Siratro } \\
\text { Common }\end{array}$ & Annual & + & + \\
\hline Phaseolus vulgaris L. & Papilionoideae & Cultivar & bean & Annual & - & - \\
\hline
\end{tabular}

Nod: "+" means nodulation observed, "_" means no nodulation

Fix: "+" means fixation observed, "-" means no fixation 


\section{Genome sequencing and annotation}

\section{Genome project history}

This organism was selected for sequencing on the basis of its environmental and agricultural relevance to issues in global carbon cycling, alternative energy production, and biogeochemical importance, and is part of the Community Sequencing Program at the U.S. Department of Energy, Joint Genome Institute (JGI) for projects of rele- vance to agency missions. The genome project is deposited in the Genomes OnLine Database [22] and standard draft genome sequence in IMG. Sequencing, finishing and annotation were performed by the JGI. A summary of the project information is shown in Table 3.

Table 3. Genome sequencing project information for Ensifer sp. strain TW10.

\begin{tabular}{lll}
\hline MIGS ID & Property & Term \\
\hline MIGS-31 & Finishing quality & Standard draft \\
MIGS-28 & Libraries used & $1 \times$ Illumina library \\
MIGS-29 & Sequencing platforms & Illumina HiSeq2000 \\
MIGS-31.2 & Sequencing coverage & $330 \times$ Illumina \\
MIGS-30 & Assemblers & Allpaths, LG version r42 328, Velvet 1.1.04 \\
MIGS-32 & Gene calling methods & Prodigal 1.4, \\
& GenBank & pending \\
& Genbank Date of Release & pending \\
& GOLD ID & Gi08835 \\
& NCBI project ID & 210334 \\
& Database: IMG & 2509276019 \\
& Project relevance & Symbiotic $\mathrm{N}_{2}$ fixation, ag riculture \\
\hline
\end{tabular}

\section{Growth conditions and DNA isolation}

Ensifer sp. TW10 was cultured to mid logarithmic phase in $60 \mathrm{ml}$ of TY rich medium [25] on a gyratory shaker at $28^{\circ} \mathrm{C}$. DNA was isolated from the cells using a CTAB (Cetyl trimethyl ammonium bromide) bacterial genomic DNA isolation method [26].

\section{Genome sequencing and assembly}

The genome of Ensifer sp. TW10 was generated at the Joint Genome Institute (JGI) using Illumina [27] technology. An Illumina std shotgun library was constructed and sequenced using the Illumina HiSeq 2000 platform which generated 14,938,244 reads totaling 2,241 $\mathrm{Mbp}$.

All general aspects of library construction and sequencing performed at the JGI can be found at the JGI website [26]. All raw Illumina sequence data was passed through DUK, a filtering program developed at JGI, which removes known Illumina sequencing and library preparation artifacts (Mingkun L, Copeland, A, and Han, J, unpublished).
The following steps were then performed for assembly: (1) filtered Illumina reads were assembled using Velvet [28] (version 1.1.04), (2) 1-3 kb simulated paired end reads were created from Velvet contigs using wgsim (https://github.com/lh3/wgsim), and (3) Illumina reads were assembled with simulated read pairs using Allpath s-LG (version r42328) [29]. Parameters for assembly steps were: 1 ) Velvet (velveth: 63 -shortPaired and velvetg: -veryclean yes exportFiltered yes -mincontiglgth 500 scaffolding no-covcutoff 10) 2) wgsim (-e $0-1$ $100-2100-\mathrm{r} \quad 0 \quad-\mathrm{R} \quad 0-\mathrm{X}$ 0) 3) Allpaths-LG (PrepareAllpathsInputs:PHRED64=1 PLOIDY=1 FRAGCOVERAGE $=125 \quad$ JUMPCOVERAGE $=25$ LONGJUMPCOV=50, RunAllpath-sLG: THREADS $=8$ RUN=stdshredpairs TARGETS=standard VAPIWARNONLY=True OVERWRITE=True). The final draft assembly contained 57 contigs in 57 scaffolds. The total size of the genome is $6.8 \mathrm{Mbp}$ and the final assembly is based on $2241 \mathrm{Mbp}$ of Illumina data, which provides an average $330 \times$ coverage of the genome. 


\section{Genome annotation}

Genes were identified using Prodigal [30] as part of the DOE-JGI annotation pipeline [31]. The predicted CDSs were translated and used to search the National Center for Biotechnology Information (NCBI) non-redundant database, UniProt, TIGRFam, Pfam, PRIAM, KEGG, COG, and InterPro databases. The tRNAScanSE tool [7] was used to find tRNA genes, whereas ribosomal RNA genes were found by searches against models of the ribosomal RNA genes built from SILVA [32]. Other non-coding RNAs such as the RNA components of the protein secretion complex and the RNase $P$ were identified by searching the genome for the corresponding Rfam profiles using INFERNAL
[33]. Additional gene prediction analysis and manual functional annotation was performed within the Integrated Microbial Genomes (IMG) platform) $[34,35]$.

\section{Genome properties}

The genome is 6,802,256 nucleotides with $61.56 \%$ GC content (Table 4) and comprised of 57 scaffolds (Figure 4) of 57 contigs. From a total of 6,546 genes, 6,473 were protein encoding and 73 RNA only encoding genes. The majority of genes (77.44\%) were assigned a putative function while the remaining genes were annotated as hypothetical. The distribution of genes into COGs functional categories is presented in Table 5.

Table 4. Genome statistics for Ensifer sp. TW10

\begin{tabular}{lrr}
\hline Attribute & Value & \% of Total \\
\hline Genome size (bp) & $6,802,256$ & 100.00 \\
DNA coding region (bp) & $5,800,968$ & 85.28 \\
DNA G+C content (bp) & $4,187,461$ & 61.56 \\
Number of scaffolds & 57 & \\
Number of contigs & 57 & \\
Total gene & 6,546 & 100.00 \\
RNA genes & 73 & 1.12 \\
rRNA operons & \multicolumn{1}{c}{1} & \\
Protein-coding genes & 6,473 & 98.88 \\
Genes with function prediction & 5,069 & 77.44 \\
Genes assigned to COGs & 5,069 & 77.44 \\
Genes assigned Pfam domains & 5,282 & 80.69 \\
Genes with signal peptides & 539 & 8.23 \\
Genes with transmembrane helices & 1,419 & 21.68 \\
\hline
\end{tabular}


Table 5. Number of protein coding genes of Ensifer sp. TW10 associated with the general COG functional categ ories.

\begin{tabular}{|c|c|c|c|}
\hline Code & Value & \%age & Description \\
\hline$J$ & 198 & 3.55 & Translation, ribosomal structure and biogenesis \\
\hline A & 0 & 0.00 & RNA processing and modification \\
\hline K & 481 & 8.61 & Transcription \\
\hline $\mathrm{L}$ & 237 & 4.24 & Replication, recombination and repair \\
\hline B & 3 & 0.05 & Chromatin structure and dynamics \\
\hline $\mathrm{D}$ & 37 & 0.66 & Cell cycle control, mitosis and meiosis \\
\hline Y & 0 & 0.00 & Nuclear structure \\
\hline V & 66 & 1.18 & Defense mechanisms \\
\hline $\mathrm{T}$ & 262 & 4.69 & Signal transduction mechanisms \\
\hline M & 298 & 5.34 & Cell wall/membrane biog enesis \\
\hline $\mathrm{N}$ & 77 & 1.38 & Cell motility \\
\hline Z & 0 & 0.00 & Cytoskeleton \\
\hline W & 1 & 0.02 & Extracellular structures \\
\hline$U$ & 132 & 2.36 & Intracellular trafficking and secretion \\
\hline $\mathrm{O}$ & 192 & 3.44 & Posttranslational modification, protein turnover, chaperones \\
\hline $\mathrm{C}$ & 322 & 5.77 & Energy production conversion \\
\hline G & 538 & 9.63 & Carbohydrate transport and metabolism \\
\hline $\mathrm{E}$ & 606 & 10.85 & Amino acid transport metabolism \\
\hline $\mathrm{F}$ & 96 & 1.72 & Nucleotide transport and metabolism \\
\hline $\mathrm{H}$ & 194 & 3.47 & Coenzyme transport and metabolism \\
\hline I & 199 & 3.56 & Lipid transport and metabolism \\
\hline$P$ & 251 & 4.49 & Inorganic ion transport and metabolism \\
\hline Q & 139 & 2.49 & Secondary metabolite biosynthesis, transport and catabolism \\
\hline $\mathrm{R}$ & 678 & 12.14 & General function prediction only \\
\hline $\mathrm{S}$ & 578 & 10.35 & Function unknown \\
\hline- & 1,477 & 22.56 & Not in COGS \\
\hline
\end{tabular}



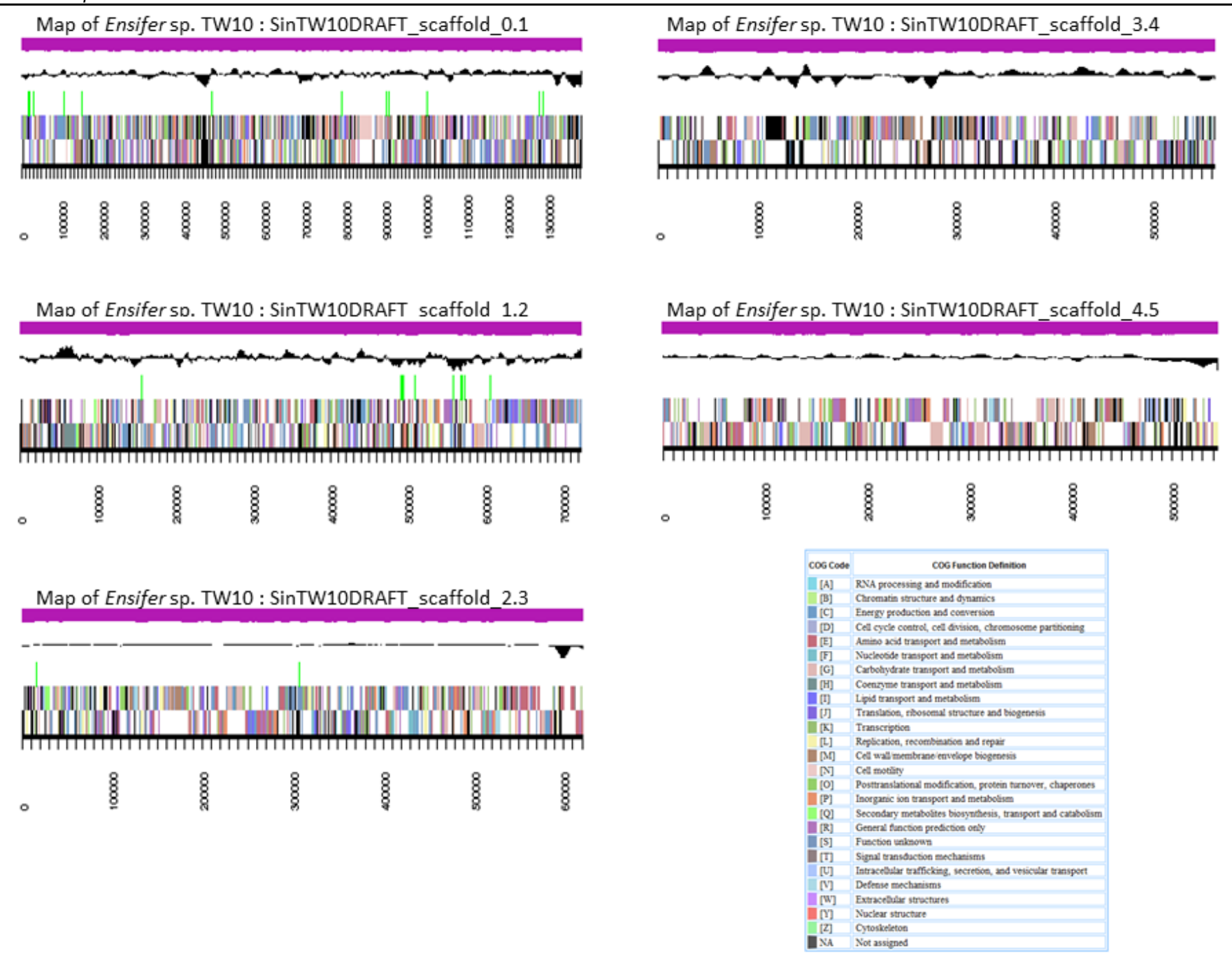

Figure 4. Graphical map of five of the largest scaffolds from the genome of Ensifer sp. TW10. From bottom to the top of each scaffold: Genes on forward strand (color by COG categ ories), Genes on reverse strand (color by COG categ ories), RNA genes (tRNAs g reen, sRNAs red, other RNAs black), GC content, GC skew.

\section{Acknowledgements}

This work was perform ed under the aus pices of the US Department of Energy's Office of Science, Biological and Environmental Research Program, and by the University of California, Lawrence Berkeley National Laboratory under contract No. DE-AC02-05CH11231, Lawrence Livermore National Laboratory under Contract No. DEAC52-07NA27344, and Los Alamos National Laboratory under contract No. DE-AC02-06NA25396. We gratefully acknowledge funding received from the Murdoch University Strategic Research Fund through the Crop

\section{References}

1. Sprent JI, Gehlot HS. Nodulated legumes in arid and semi-arid environments: are they important? Plant Ecol Divers 2010; 3:211-219. http://dx.doi.org/10.1080/17550874.2010.53874 $\underline{0}$ and Plant Research Institute (CaPRI), the GRD C National Rhizobium Program (UMU00032), the Council of Scientific and Industrial Research (CSIR) for a fellowship for Nisha Tak, the Departm ent of Biotechnology (India) for a research grant (BT/PR11461/AGR/21/270/2008) and the Commonwealth of Australia for an Australia India Senior Visiting Fellowship for Ravi Tiwari. 
an Thar Desert. Natural Product Radiance 2004; 3:69-74.

4. Sen DN. Non-conventional food and some medicinal plant resources of Indian Desert. In: Purkayashtha RP, editor. Economic plants and microbes: Today and Tomorrow's Printers and Publishers, New Delhi; 1991. p 67-76.

5. Gehlot HS, Panwar D, Tak N, Tak A, Sankhla IS, Poonar N, Parihar R, Shekhawat NS, Kuma M, Tiwari R, et al. Nodulation of leg umes from the Thar Desert of India and molecular characterization of their rhizobia. Plant Soil 2012; 357:227243. http://dx.doi.org/10.1007/s11104-012-1143$\underline{5}$

6. Field D, Garrity G, Gray T, Morrison N, Seleng ut J, Sterk P, Tatusova T, Thomson N, Allen M, Angiuoli SV, et al. Towards a richer description of our complete collection of genomes and metagenomes "Minimum Information about a Genome Sequence " (MIGS) specification. Nat Biotechnol 2008; 26:541-547. PubMed http://dx.doi.org/10.1038/nbt1360

7. Woese CR, Kandler O, Wheelis ML. Towards a natural system of org anisms: proposal for the domains Archaea, Bacteria, and Eucarya. Proc Natl Acad Sci USA 1990; 87:4576-4579. PubMed http://dx.doi.org/10.1073/pnas.87.12.4576

8. Garrity GM, Bell JA, Lilburn T. Phylum XIV. Proteobacteria phyl. nov. In: Garrity GM, Brenner DJ, Krieg NR, Staley JT (eds), Bergey's Manual of Systematic Bacteriology, Second Edition, Volume 2, Part B, Springer, New York, 2005, p. 1.

9. Garrity GM, Bell JA, Lilburn T. Class I. Alphaproteobacteria class. nov. In: Garrity GM, Brenner DJ, Krieg NR, Staley JT (eds), Bergey's Manual of Systematic Bacteriology, Second Edition, Volume 2, Part C, Springer, New York, 2005, p. 1.

10. Validation List No. 107. List of new names and new combinations previously effectively, but not validly, published. Int / Syst Evol Microbiol 2006; 56:1-6. PubMed http://dx.doi.org/10.1099/ijs.0.64188-0

11. Kuykendall LD. Order VI. Rhizobiales ord. nov. In: Garrity GM, Brenner DJ, Kreig NR, Staley JT, editors. Bergey's Manual of Systematic Bacteriology. Second ed: New York: Springer - Verlag; 2005. p 324 .

12. Skerman VBD, McGowan V, Sneath PHA. Approved Lists of Bacterial Names. Int J Syst Bacteriol 1980; 30:225-420. http://dx.doi.org/10.1099/00207713-30-1-225
13. Conn HJ. Taxonomic relationships of certain nonsporeforming rods in soil. J Bacterio/ 1938;

36: $320-321$.

14. Casida LE. Ensifer adhaerens gen. nov., sp. nov.: a bacterial predator of bacteria in soil. Int J Syst Bacteriol 1982; 32:339-345. http://dx.doi.org/10.1099/00207713-32-3-339

15. Young JM. The genus name Ensifer Casida 1982 takes priority over Sinorhizobium Chen et al. 1988, and Sinorhizobium morelense Wang et al. 2002 is a later synonym of Ensifer adhaerens Casida 1982. Is the combination Sinorhizobium adhaerens (Casida 1982) Willems et al. 2003 legitimate? Request for an Opinion. Int J Syst Evol Microbiol 2003; 53:2107-2110. PubMed http://dx.doi.org/10.1099/ijs.0.02665-0

16. Judicial Commission of the International Committee on Systematics of Prokaryotes. The genus name Sinorhizobium Chen et al. 1988 is a later synonym of Ensifer Casida 1982 and is not conserved over the latter genus name, and the species name 'Sinorhizobium adhaerens' is not validly published. Opinion 84. Int J Syst Evol Microbiol 2008; 58:1973. PubMed http://dx.doi.org/10.1099/ijs.0.2008/005991-0

17. Agents B. Technical rules for biological agents. TRBA (http://www.baua.de) :466.

18. Ashburner M, Ball CA, Blake JA, Botstein D, Butler H, Cherry JM, Davis AP, Dolinski K, Dwight SS, Eppig JT, et al. Gene ontology: tool for the unification of biology. The Gene Ontology Consortium. Nat Genet 2000; 25:25-29. PubMed http://dx.doi.org/10.1038/75556

19. Tamura K, Peterson D, Peterson N, Stecher G, Nei M, Kumar S. MEGA5: Molecular Evolutionary Genetics Analysis using Maximum Likelihood, Evolutionary Distance, and Maximum Parsimony Methods. Mol Biol Evol 2011; 28:2731-2739. PubMed http://dx.doi.org/10.1093/molbev/msr121

20. Nei M, Kumar S. Molecular Evolution and Phylog enetics. New York: Oxford University Press; 2000.

21. Felsenstein J. Confidence limits on phylog enies: an approach using the bootstrap. Evolution 1985; 39:783-791. http://dx.doi.org/10.2307/2408678

22. Liolios K, Mavromatis K, Tavernarakis N, Kyrpides NC. The Genomes On Line Database (GOLD) in 2007: status of genomic and metagenomic projects and their associated metadata. Nucleic Acids Res 2008; 36:D475-D479. PubMed http://dx.doi.org/10.1093/nar/gkm884 
23. Vincent JM. A manual for the practical study of the root-nodule bacteria. International Biological Prog ramme. UK: Blackwell Scientific Publications, Oxford; 1970.

24. Gehlot HS, Tak N, Kaushik M, Mitra S, Chen WM, Poweleit N, Panwar D, Poonar N, Parihar R, Tak A, et al. An invasive Mimosa in India does not adopt the symbionts of its native relatives. Ann Bot (Lond) 2013; 112:179-196. PubMed http://dx.doi.org/10.1093/aob/mct112

25. Reeve WG, Tiwari RP, Worsley PS, Dilworth MJ, Glenn AR, Howieson JG. Constructs for insertional mutag enesis, transcriptional signal localization and gene regulation studies in root nodule and other bacteria. Microbiology 1999; 145:1307-1316. PubMed http://dx.doi.org/10.1099/13500872-145-6-1307

26. DOE Joint Genome Institute user home.http://my.jgi.doe.gov/general/index.html

27. Bennett S. Solexa Ltd. Pharmacogenomics 2004; 5:433-438. PubMed http://dx.doi.org/10.1517/14622416.5.4.433

28. Zerbino DR. Using the Velvet de novo assembler for short-read sequencing technolog ies. Current Protocols in Bioinformatics 2010; Chapter 11:Unit 115.

29. Gnerre S, MacCallum I, Przybylski D, Ribeiro FJ, Burton JN, Walker BJ, Sharpe T, Hall G, Shea TP, Sykes $\mathrm{S}$, et al. High-quality draft assemblies of mammalian genomes from massively parallel se- quence data. Proc Natl Acad Sci USA 2011;

108:1513-1518. PubMed

http://dx.doi.org/10.1073/pnas.1017351108

30. Hyatt D, Chen GL, Locascio PF, Land ML, Larimer FW, Hauser LJ. Prodigal: prokaryotic gene recognition and translation initiation site identification. BMC Bioinformatics 2010; 11:119. PubMed http://dx.doi.org/10.1186/1471-2105-11-119

31. Mavromatis K, Ivanova NN, Chen IM, Szeto E, Markowitz VM, Kyrpides NC. The DOE-JGI Standard operating procedure for the annotations of microbial genomes. Stand Genomic Sci 2009; 1:63-67. PubMed http://dx.doi.org/10.4056/sig s.632

32. Pruesse E, Quast C, Knittel K. Fuchs BdM, Ludwig W, Peplies J, Glöckner FO. SILVA: a comprehensive online resource for quality checked and aligned ribosomal RNA sequence data compatible with ARB. Nucleic Acids Res 2007; 35:71887196. PubMed http://dx.doi.org/10.1093/nar/gkm864

33. INFERNAL. http://infernal.janelia.org

34. Markowitz VM, Mavromatis K, Ivanova NN, Chen IM, Chu K, Kyrpides NC. IMG ER: a system for microbial genome annotation expert review and curation. Bioinformatics 2009; 25:22 71-22 78.

PubMed http://dx.doi.org/10.1093/bioinformatics/btp393

35. DOE Joint Genome Institute. (http://img.jgi.doe.gov/er) 